\title{
Age-Related Changes of Cholinergic Markers in the Rat Brain
}

\author{
Fumie Yufu, Toru Egashira and Yasumitsu Yamanaka \\ Department of Pharmacology, Oita Medical University, 1-1 Idaigaoka, Hasama-machi, Oita 879-55, Japan
}

Received May 10, 1994 Accepted July 12, 1994

\begin{abstract}
To evaluate whether any degenerative changes affect the brain cholinergic systems during natural aging, we compared various cholinergic biochemical markers (number of muscarinic receptors, mAChR; choline acetyltransferase activity, ChAT; acetylcholinesterase activity, AChE; and sodium-dependent high affinity choline uptake) in the cortical (CR) and subcortical (SS) regions of the brains of aged (24 month) and young (2 month) rats. Using $\left[{ }^{3} \mathrm{H}\right]$-quinuclidinyl benzilate $\left(\left[{ }^{3} \mathrm{H}\right]-\mathrm{QNB}\right)$ as the ligand of muscarinic receptor binding, the numbers of $\mathrm{mAChR}$ decreased about $30 \%$ in both the CR and the SS of aged rats compared with those in young rats, while a significant age-related increase in the affinity of mAChR was observed. $\left[{ }^{3} \mathrm{H}\right]-\mathrm{QNB}$ binding in both the young and aged rat brain was displaced markedly by pirenzepine, while $\left[{ }^{3} \mathrm{H}\right]-\mathrm{QNB}$ binding in the SS of the aged rat brain was displaced at low concentrations of atropine. The $\mathrm{V}_{\max }$ values of ChAT and AChE also decreased about $20-30 \%$ compared with those of young rats. The sodium-dependent high affinity choline uptake was lower in the crude synaptosomal fraction prepared from aged rat brain than in young brain. Hemicholinium-3 inhibited the choline uptake in young rat brain at a concentration range of $1 \mu \mathrm{M}-10 \mathrm{nM}$, but choline uptake in aged brain was insensitive to hemicholinium-3. These results indicate that natural aging brings about a diffuse and multiple depletion of various biochemical markers in cholinergic neurons.
\end{abstract}

Keywords: Aged rat, Muscarinic receptor, Acetylcholinesterase, Choline acetyltransferase, Sodium-dependent choline uptake

Numerous neurochemical studies using both animals and humans have revealed age-related changes in neurotransmitter enzyme activities and receptor binding (1-4). Age-related memory disorders, including Alzheimer's disease, show a substantial decrease in cholinergic markers, such as choline acetyltransferase (ChAT), acetylcholinesterase (AChE) and the number of muscarinic receptors ( $\mathrm{mAChR}$ ), in the hippocampal formation and other cortical and basal forebrain structures (5-9). However, there are conflicting reports from both human and animal studies. Many studies have shown that the levels of ChAT and mAChR are unchanged (10) or slightly increased with age (11), but decreased levels have also been found (12). These discrepancies could be due in part to the differences in strain or species $(13,14)$, sex $(15)$, tissue sampling $(16,17)$, assay procedures $(18)$ or the choice of time points during the life cycle used for comparison $(19,20)$.

Electrolytic or neurotoxic lesions of the nucleus basalis magnocellularis (NBM) reduce cortical ChAT activity, AChE activity, acetylcholine (ACh) release and choline uptake (21-23). Moreover, NBM-lesioned rats showed impaired acquisition of a passive avoidance response (24). These data should be useful for establishing a model of Alzheimer's disease which could be used to study therapeutic drugs and methods. In the meantime, investigation of brain cholinergic systems in aged laboratory animals could provide useful information pertaining to age and age-related disorders in humans.

The present study examines the characteristics of certain cholinergic markers (ChAT and AChE activity, number of muscarinic binding sites and choline uptake) in the cortex and subcortical structures in aged and young rats.

\section{MATERIALS AND METHODS}

\section{Animals}

Male, Sprague-Dawley rats aged 6 weeks (young) and 24 month (aged) were used. The rats were housed in a controlled enviroment $\left(25 \pm 2^{\circ} \mathrm{C}, 50 \pm 5 \%\right.$ humidity, lit between 6:00 and 18:00 hours) with food and water available ad libitum.

Under ether anesthesia, the rats were sacrificed by decapitation. The brain was quickly removed from the 
skull and dissected into two parts: the forebrain and temporal, parietal and occipital lobes (which were combined for all assays and are generically referred to below as the cortical regions, CR) and the hippocampus, globus pallidus, thalamus, nucleus basalis of Meynert, caudate nucleus, putamen and striatum (which were combined for all assays and are generically referred to below as subcortical structures, SS). To minimize individual variations, tissues from at least five rats were pooled for use in each experiment and stored at $-80^{\circ} \mathrm{C}$.

\section{Muscarinic receptor binding assay}

Brain tissues were homogenized in 5 vol. (wt./vol.) of $50 \mathrm{mM}$ Tris-HCl buffer, $\mathrm{pH} 7.5$. The homogenates were centrifuged at $900 \times \mathrm{g}$ for $10 \mathrm{~min}$. The supernatants were again centrifuged at $12,000 \times g$ for 20 min. Pellets were resuspended in $10 \mathrm{mM}$ Tris- $\mathrm{HCl}$ buffer containing $5 \mathrm{mM}$ $\mathrm{MgSO}_{4}, \mathrm{pH} 7.5$, to a protein concentration of $1.0 \mathrm{mg} / \mathrm{ml}$ yielding a crude synaptosomal fraction. The apparent dissociation constant $\left(\mathrm{K}_{\mathrm{d}}\right)$ and the density of muscarinic receptors $\left(\mathbf{B}_{\text {max }}\right)$ in the crude synaptosomal fraction were assayed according to the method of Yamamura and Snyder (25) using $\left[{ }^{3} \mathrm{H}\right]$-quinuclidinyl benzilate $\left(\left[{ }^{3} \mathrm{H}\right]\right.$ $\mathrm{QNB}$ ) as the specific ligand. Aliquots of the crude synaptosomal fraction $(100 \mu \mathrm{l}, 1 \mathrm{mg}$ protein $/ \mathrm{ml})$ were incubated in a total volume of $1.0 \mathrm{ml}$ at $37^{\circ} \mathrm{C}$ for $30 \mathrm{~min}$ with various concentrations of $\left[{ }^{3} \mathrm{H}\right]$-QNB $(0.04-0.6 \mathrm{nM})$ in 10 $\mathrm{mM}$ Tris- $\mathrm{HCl}$ buffer containing $5 \mathrm{mM} \mathrm{MgSO}_{4}$. After incubation, $4 \mathrm{ml}$ of ice-cold $10 \mathrm{mM}$ Tris-HCl buffer, containing $145 \mathrm{mM} \mathrm{NaCl}, \mathrm{pH} 7.5$, was added to the aliquots, and the bound ligand was separated from the free ligand using rapid filtration. The filter papers (GF/B glass filters, Whatman) were washed four times with the same ice-cold buffer. After the filters dried overnight, $10 \mathrm{ml}$ of Triton $\mathrm{X}$-100-toluene scintillation fluid was added to each. Samples were measured by a liquid scintillation spectrometer with an efficiency of $47 \%$. Specific binding was determined as the difference between measurements in the presence and absence of atropine $(1 \mu \mathrm{M})$. Typically, [ $\left.{ }^{3} \mathrm{H}\right]-\mathrm{QNB}$ was used at a concentration of $0.04 \mathrm{nM}$ for experiments involving the competitive displacement of $\left[{ }^{3} \mathrm{H}\right]-$ QNB binding by atropine or pirenzepine.

\section{Choline acetyltransferase activity assay}

Choline acetyltransferase (ChAT) activity was determined by a minor modification of the radiometric method of Fonnum (26) using $\left[{ }^{3} \mathrm{H}\right]$-acetyl coenzyme $A$ as a substrate. Each brain tissue was homogenized in 5 vol. of

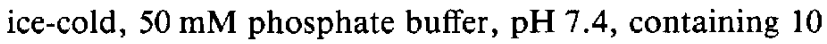
mM EDTA and $2.5 \%$ Triton X-100. These preparations were allowed to stand for $15 \mathrm{~min}$ at $0^{\circ} \mathrm{C}$ and were then centrifuged at $20,000 \times \mathrm{g}$ for $10 \mathrm{~min}$. The protein content in the resultant supernatant was adjusted to $1 \mathrm{mg} / \mathrm{ml}$ with

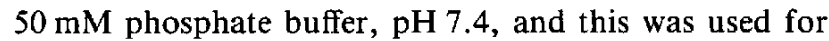
ChAT analysis. The incubation solutions contained 0.2 $\mathrm{mM}\left[{ }^{3} \mathrm{H}\right]$-acetyl coenzyme $\mathrm{A}$, various concentrations of choline bromide (1-10 mM), $300 \mathrm{mM} \mathrm{NaCl}, 50 \mathrm{mM}$ phosphate buffer (pH 7.4), $0.1 \mathrm{mM}$ physostigmine and $20 \mathrm{mM}$ EDTA. Eight microliters of the enzyme preparation and 20- $\mu \mathrm{l}$ aliquots of the incubation solution were combined and incubated at $37^{\circ} \mathrm{C}$ for $15 \mathrm{~min}$. The reaction was terminated by adding $1 \mathrm{ml}$ of cold, $10 \mathrm{mM}$ phosphate buffer, $\mathrm{pH} 7.4$, and $500 \mu \mathrm{l}$ of Kalibor solution in acetonitrile ( 5 $\mathrm{mg} / \mathrm{ml}$ ). The reaction products were extracted with $2.0 \mathrm{ml}$ of toluene. Samples of the extract were mixed with Triton $\mathrm{X}-100$-toluene scintillation fluid and their radioactivities measured by a liquid scintillation spectrometry. The enzymic activities were calculated from the $\mathrm{dpm}$ values and expressed as nanomoles of acetylcholine synthesized $/ \mathrm{min}$ per mg protein. The values of the apparent $K_{m}$ and $V_{\max }$ were obtained from Lineweaver-Burk plots corresponding to various concentrations of choline bromide.

\section{Acetylcholinesterase activity assay}

Acetylcholinesterase (AChE) activity was measured according to the method of Ellman (27). Brain tissues were homogenized in 5 vol. (wt./vol.) of $50 \mathrm{mM}$ Tris- $\mathrm{HCl}$ buffer, pH 7.5. The homogenates were centrifuged at $900 \times \mathrm{g}$ for $10 \mathrm{~min}$. The supernatants were again centrifuged at $12,000 \times g$ for $20 \mathrm{~min}$. The resultant pellets were suspended in Tris- $\mathrm{HCl}$ buffer containing $5 \mathrm{mM} \mathrm{MgSO}$, $\mathrm{pH} 7.5$, at a protein concentration of $1.0 \mathrm{mg} / \mathrm{ml}$, yielding the crude synaptosomal fraction. The $50-\mu l$ aliquot of synaptosomal preparation was incubated for $5 \mathrm{~min}$ at $37^{\circ} \mathrm{C}$ in $100 \mathrm{mM}$ phosphate buffer, $\mathrm{pH} 8.0$, containing $10 \mathrm{mM} 5,5^{\prime}$-dithiobis-2-nitrobenzoic acid in a final volume of $3.5 \mathrm{ml}$. After adding $20 \mu \mathrm{l}$ of various concentrations of acetylthiocholine $(47-473 \mu \mathrm{M})$, the absorbance at $412 \mathrm{~nm}$ was measured with a Hitachi 557 spectrophotometer. The enzymic activity was expressed as nanomoles of acetylthiocholine hydrolyzed/min per $\mathrm{mg}$ of protein. The apparent $V_{\max }$ and $\mathrm{K}_{\mathrm{m}}$ values were obtained from Lineweaver-Burk plots corresponding to various concentrations of acetylthiocholine.

\section{Sodium dependent high affinity $\left.I^{3} \mathrm{H}\right]$-choline uptake assay}

The sodium-dependent high affinity $\left[{ }^{3} \mathrm{H}\right]$-choline uptake was assayed according to the modified method of Sorimachi and Kataoka (28). The brain tissues were homogenized in 9 vol. of $0.32 \mathrm{M}$ sucrose, $\mathrm{pH}$ 7.4. Crude synaptosomal fractions were obtained by differential centrifugation on conventional discontinuous sucrose density gradients. The resulting pellets were suspended in Krebs-Ringer bicarbonate buffer, $\mathrm{pH} 7.4$, containing 140 $\mathrm{mM} \mathrm{NaCl}, 5 \mathrm{mM} \mathrm{KCl}, 1 \mathrm{mM} \mathrm{CaCl}{ }_{2}, 1 \mathrm{mM} \mathrm{MgSO}_{4}, 1 \mathrm{mM}$ $\mathrm{NaH}_{2} \mathrm{PO}_{4}, 20 \mathrm{mM} \mathrm{NaHCO}$ and $11 \mathrm{mM}$ glucose. The 
Table 1. Binding of $\left[{ }^{3} \mathrm{H}\right]-\mathrm{QNB}$ to muscarinic ACh receptors in brains of young and aged rats

\begin{tabular}{lcccc}
\hline & \multicolumn{2}{c}{ Young rat } & \multicolumn{2}{c}{ Aged rat } \\
& $\mathrm{K}_{\mathbf{d}}$ & $\mathrm{B}_{\max }$ & $\mathrm{K}_{\mathrm{d}}$ & $\mathbf{B}_{\max }$ \\
\hline Cortical regions & $\mathbf{0 . 1 2 3 \pm 0 . 0 0 1}$ & $2.35 \pm 0.15$ & $0.107 \pm 0.005^{*}$ & $1.63 \pm 0.03^{*}$ \\
Subcortical structures & $0.087 \pm 0.008$ & $1.16 \pm 0.17$ & $0.042 \pm 0.006^{*}$ & $0.56 \pm 0.03^{*}$ \\
\hline
\end{tabular}

Binding data were derived from saturation analysis. Binding for each concentration of radioligand was measured in triplicate, and nonspecific binding was defined as the binding in the presence of $1 \mu \mathbf{M}$ atropine, also in triplicate. The maximal density of muscarinic receptors $\left(B_{\max }\right)$ and the apparent dissociation constant $\left(\mathrm{K}_{\mathrm{d}}\right)$ for $\left[{ }^{3} \mathrm{H}\right]$-QNB binding were determined graphically by Scatchard analysis and expressed as the mean \pm S.E. of the values obtained for five rats. $\mathbf{B}_{\max }: \mathrm{pmol} / \mathrm{mg}$ protein, $\mathrm{K}_{\mathrm{d}}: \mathbf{n M}$, $\mathrm{CR}$ : cortical regions, SS: subcortical structures. ${ }^{*}: \mathbf{P}<0.05$, compared with young rats.

$100-\mu 1$ samples of crude synaptosomes $(200 \mu \mathrm{g}$ protein/tube) were preincubated at $37^{\circ} \mathrm{C}$ for $5 \mathrm{~min}$ in the same buffer oxygenated with a $95 \% \mathrm{O}_{2}-5 \% \mathrm{CO}_{2}$ gas mixture. $\left[{ }^{3} \mathrm{H}\right]$-Choline chloride $(0.25-4.0 \mu \mathrm{M})$ was then added, and the solution was incubated at $37^{\circ} \mathrm{C}$ for $4 \mathrm{~min}$. Reactions were terminated by rapid filtration of the crude synaptosomes under reduced pressure through Whatman GF/B glass fiber filters. Each filter was immediately washed four times with $4 \mathrm{ml}$ of ice-cold saline. The filters were then dried, and the radioactivities were measured by liquid scintillation spectrometry after adding Triton $\mathrm{X}$ 100-toluene scintillation fluid. The specific choline uptake was defined as the difference between measurements made with the above buffer and those made with a sodium-free buffer $\left(\mathrm{Na}^{+}\right.$replaced with $280 \mathrm{mM}$ sucrose and $21 \mathrm{mM}$ Tris- $\mathrm{HCl}$ ). The values of apparent $\mathrm{V}_{\max }$ and $\mathrm{K}_{\mathrm{m}}$ were obtained from Lineweaver-Burk plots.

\section{Proteins}

The protein content was determined by the method of Lowry et al. (29) using bovine serum albumin as the standard.

\section{Materials}

$\left[{ }^{3} \mathrm{H}\right]$-Quinuclidinyl benzilate $\left(\left[{ }^{3} \mathrm{H}\right]-\mathrm{QNB}\right)(2.22-3.22$ $\mathrm{TBq} / \mathrm{mmol})$ and [methyl- $\left.{ }^{3} \mathrm{H}\right]$-choline chloride $(2.22-$ $3.33 \mathrm{TBq} / \mathrm{mmol}$ ) were purchased from New England Nuclear (Boston, MA, USA). $\left[{ }^{3} \mathrm{H}\right]$-Acetyl coenzyme A (111-122 GBq/mmol) was purchased from Amersham (Buckinghamshire, England). Atropine sulfate, acetyl coenzyme A, choline bromide, $p$-chloromercuricbenzoic acid (PCMB), hemicholinium-3 and physostigmine sulfate were obtained from Sigma Chemical Co. (St. Louis, MO, USA). Pirenzepine hydrochloride was supplied by Boehringer Ingelheim, Kawanishi. All other chemicals were obtained from Wako Pure Chemical Industries, Ltd. (Osaka).

\section{Statistics}

Results are expressed as the mean or means \pm S.E. for four or five rats. The significance of the mean difference was determined by Student's $t$-test for unpaired data.
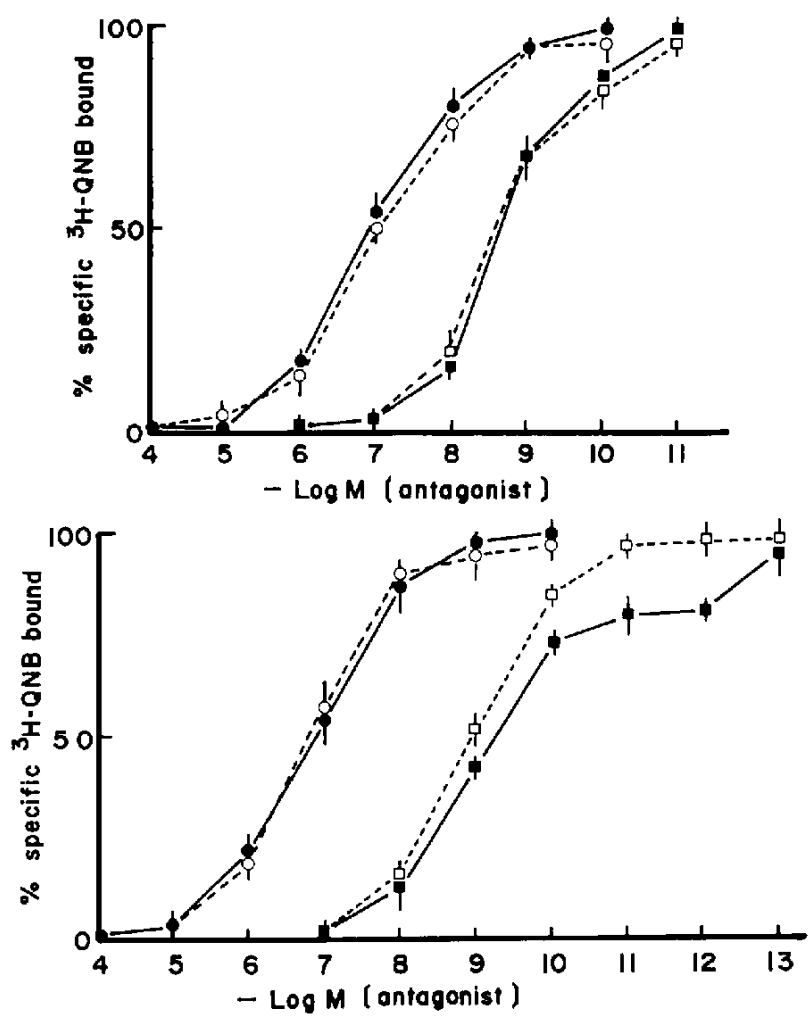

Fig. 1. Inhibition of specific $\left[{ }^{3} \mathrm{H}\right]-\mathrm{QNB}$ binding by pirenzepine and atropine in young and aged rat brain. Membrane preparations of each brain part were incubated with $0.04 \mathrm{nM}\left[{ }^{3} \mathrm{H}\right]-\mathrm{QNB}$ and various concentrations of pirenzepine and atropine in $10 \mathrm{mM}$ Tris- $\mathrm{HCl}$ buffer (pH 7.4) containing $5 \mathrm{mM} \mathrm{MgSO}_{4}$ for $30 \mathrm{~min}$ at $37^{\circ} \mathrm{C}$. Each point represents the mean \pm S.E. of the specific $\left[{ }^{3} \mathrm{H}\right]$-QNB binding values determined in three separate experiments. Top: cerebral cortex, bottom: subcortical structure. Pirenzepine in aged: - pirenzepine in young: $--0_{--}$, atropine in aged: -- , atropine in young: - . $\square$ - - rat brain. 
Table 2. Choline acetyltransferase activities in brains of young and aged rats

\begin{tabular}{lcccc}
\hline \multirow{2}{*}{ ChAT } & \multicolumn{2}{c}{ Young rat } & \multicolumn{2}{c}{ Aged rat } \\
& $\mathrm{V}_{\max }$ & $\mathrm{K}_{\mathrm{m}}$ & $\mathrm{V}_{\max }$ & $\mathrm{K}_{\mathrm{m}}$ \\
\hline Cortical regions & $1.89 \pm 0.33$ & $2.82 \pm 0.15$ & $1.58 \pm 0.17^{*}$ & $2.61 \pm 0.58$ \\
Subcortical structures & $1.29 \pm 0.18$ & $9.21 \pm 0.51$ & $0.92 \pm 0.09^{*}$ & $8.14 \pm 2.30$ \\
\hline
\end{tabular}

Each value is expressed as the mean \pm S.E. for five rats. $V_{\max }$ and $K_{m}$ values were determined from Lineweaver-Burk double reciprocal plots of values obtained from graphic representations of the kinetic data. $\mathrm{V}_{\max }$ : $\mathrm{nmol} / \mathrm{min}$ per $\mathrm{mg}$ protein, $\mathrm{K}_{\mathrm{m}}$ : $\mathrm{mM}$ against choline bromide. ${ }^{*}: \mathbf{P}<0.05$, compared with young rats.

\section{RESULTS}

\section{Muscarinic receptors}

To determine whether muscarinic receptors in the central nervous system are affected during natural aging, $\mathrm{ki}-$ netic analysis of $\left[{ }^{3} \mathrm{H}\right]$-QNB binding in two parts (CR and SS) of young and aged rat brain was performed. Table 1 shows a slight age-related reduction in the apparent dissociation constant for $\left[{ }^{3} \mathrm{H}\right]-\mathrm{QNB}\left(\mathrm{K}_{\mathrm{d}}\right)$ in the CR and SS. A significant age-related decrease was found in the density of muscarinic receptors $\left(B_{\max }\right)$ in the CR and SS. Changes in the values of $B_{\max }$ and $K_{d}$ with age are more marked in the SS than in the CR.

The effects of the mAChR antagonists pirenzepine and atropine on $\left[{ }^{3} \mathrm{H}\right]-\mathrm{QNB}$ binding sites in the CR and the SS of young and aged rats were compared. Figure 1 shows that $\left[{ }^{3} \mathrm{H}\right]-\mathrm{QNB}$ bindings were strongly displaced with increasing concentrations of pirenzepine and atropine. Inhi- bition curves of pirenzepine in aged rats were similar to those in young rats. There was no difference between the atropine inhibition curve in the $\mathrm{CR}$ in young rats and that in aged rats. The inhibition of $\left[{ }^{3} \mathrm{H}\right]-\mathrm{QNB}$ binding at lower concentration of atropine $(1-100 \mathrm{pM})$ was $20 \%$ lower in the SS of aged rats as compared with that of young rats.

\section{Choline acetyltransferase (ChAT) activity}

Table 2 shows that with advancing age, the value of $\mathrm{V}_{\max }$ of ChAT declined significantly in both the CR and SS. However, no significant age-related differences were observed in the $\mathrm{K}_{\mathrm{m}}$ values.

It is known that PCMB inhibits ChAT (30), and Fig. 2 shows a marked PCMB-induced inhibition of ChAT activity in the $\mathrm{CR}$ of both young and aged rats. ChAT activity in the SS of young rats was more sensitive to PCMB than that of aged rats.
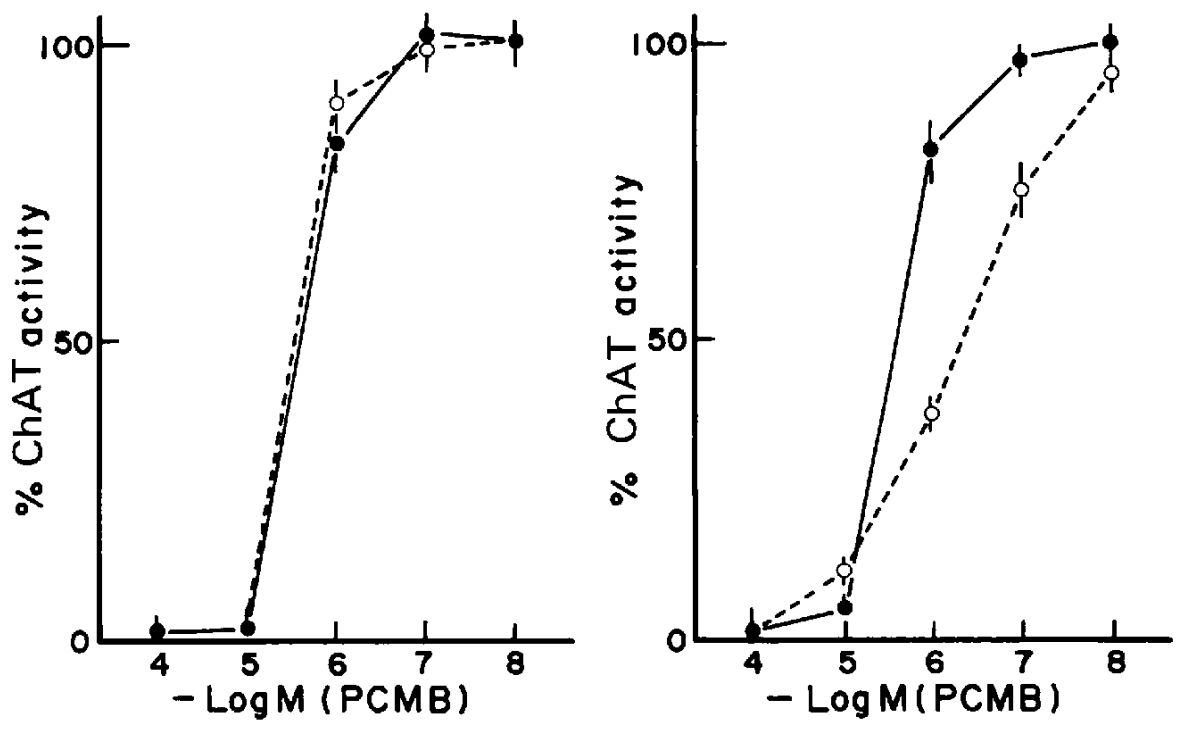

Fig. 2. Inhibition by p-chloromercuricbenzoic acid (PCMB) on choline acetyltransferase (ChAT) activity in young and aged rat brain. An enzyme solution of each brain part was incubated with the substrate mixture for 15 min at $37^{\circ} \mathrm{C}$ with various concentrations of PCMB. Symbols with bars represent the mean \pm S.E. of three separate experiments. Left: cerebral cortex, right: subcortical structure. Aged: - -, young: - - - rat brain. 
Table 3. Acetylcholinesterase activities in brains of young and aged rats

\begin{tabular}{lcccc}
\hline \multirow{2}{*}{ AChE } & \multicolumn{2}{c}{ Young rat } & \multicolumn{2}{c}{ Aged rat } \\
& $\mathrm{V}_{\max }$ & $\mathrm{K}_{\mathrm{m}}$ & $\mathrm{V}_{\max }$ & $\mathrm{K}_{\mathrm{m}}$ \\
\hline Cortical regions & $283.8 \pm 10.2$ & $83.2 \pm 16.0$ & $205.0 \pm 13.0^{*}$ & $77.9 \pm 8.6$ \\
Subcortical structures & $188.7 \pm 8.3$ & $56.0 \pm 3.3$ & $122.5 \pm 5.3^{*}$ & $58.5 \pm 5.2$ \\
\hline
\end{tabular}

Each value is expressed as the mean \pm S.E. for five rats. AChE activity was spectrophotometrically determined with acetylthiocholine as a substrate. $V_{\max }$ and $K_{m}$ values were estimated from Lineweaver-Burk double reciprocal plots of values obtained from graphic representations of the kinetic data. $\mathrm{V}_{\max }: \mathrm{nmol} / \mathrm{min}$ per $\mathrm{mg}$ protein, $\mathrm{K}_{\mathrm{m}}: \mu \mathrm{M},{ }^{*}: \mathrm{P}<0.05$, compared with young rats.

\section{Acetylcholinesterase activity}

As with ChAT, the value of $\mathrm{V}_{\max }$ of AChE was $28 \%$ less in the CR of aged rats than in young rats and $35 \%$ less in the SS of aged rats than in young rats (Table 3 ). No significant difference was observed between the $K_{m}$ values of AChE in young and aged rats.

No difference was found in the inhibition of AChE activity produced by physostigmine between young and aged rats (Fig. 3).

\section{Sodium-dependent high affinity choline uptake}

The values of both $K_{m}$ and $V_{\max }$ of sodium-dependent high affinity $\left[{ }^{3} \mathrm{H}\right]$-choline uptake were significantly lower in the aged rat brain than those of the young rat brain. Aged rats showed a $40 \%$ lower value of $V_{\max }$ in the $C R$ and a $60 \%$ lower value of $\mathrm{V}_{\max }$ in the SS (Table 4). Aged rats showed a $57 \%$ lower value of $K_{m}$ in the $C R$ and a
$43 \%$ lower value of $K_{m}$ in the SS.

Figure 4 shows the effect of hemicholinium-3 (HC-3) on sodium-dependent high affinity $\left[{ }^{3} \mathrm{H}\right]$-choline uptake in rat brain synaptosomes. In young rats, the uptake was inhibited strongly by low concentrations of $\mathrm{HC}-3$. However, in aged rats, the uptake was not completely inhibited, even at high concentrations of HC-3. The residual activities at $10^{-4} \mathrm{M} \mathrm{HC}-3$ were $20 \%$ in the $\mathrm{CR}$ and $30 \%$ in the SS.

\section{DISCUSSION}

The age-related decrease in neurochemical markers in rodents supports their use as a model of human aging. In particular, the muscarinic binding in the brain of rats is frequently used in aging research.

Waller and London (31) reported that the affinity for
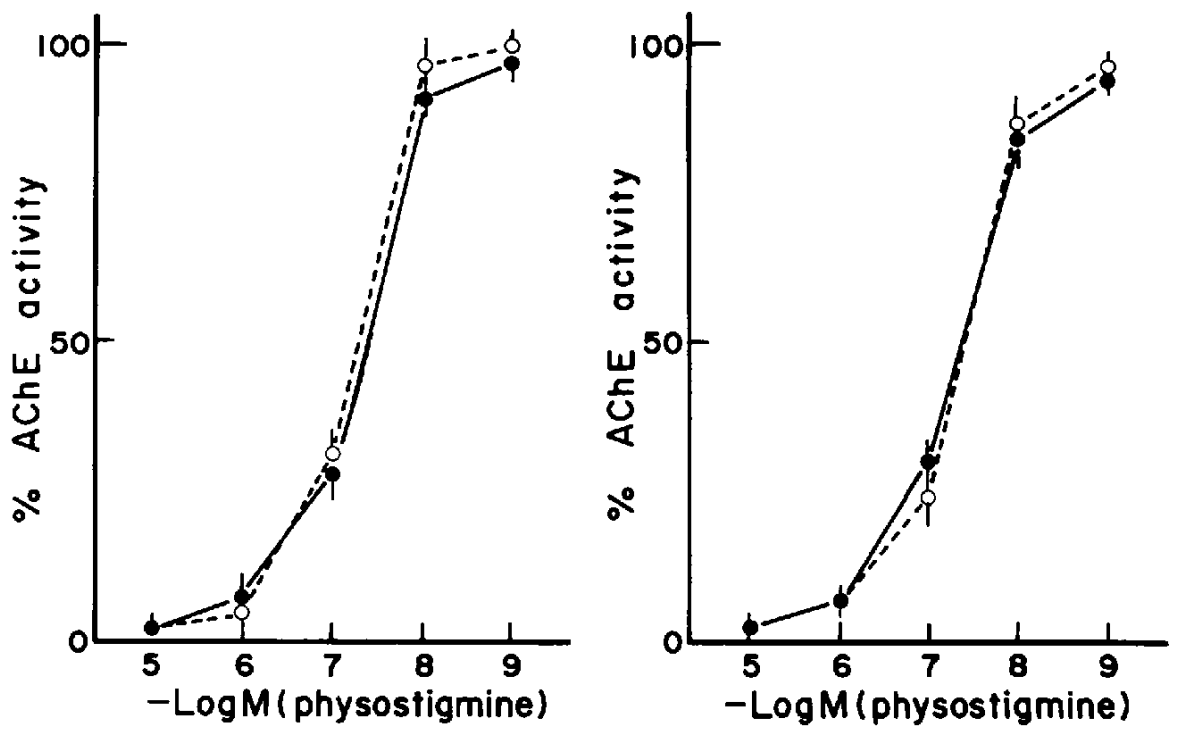

Fig. 3. Inhibition by physostigmine on acetylcholinesterase activity in young and aged rat brain. An enzyme solution of each

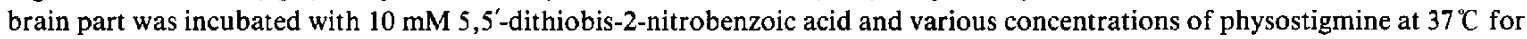
$5 \mathrm{~min}$; and after adding acetylthiocholine as the substrate, the absorbance at $412 \mathrm{~nm}$ was measured with a spectrophotometer. Symbols with bars represent the mean \pm S.E. of three separate experiments. Left: cerebral cortex, right: subcortical structure. Aged: $-\mathrm{O}$, young: $-\bigcirc-$ rat brain. 
Table 4. Sodium-dependent high affinity choline uptake in brains of young and aged rats

\begin{tabular}{lccrc}
\hline & \multicolumn{2}{c}{ Young rat } & \multicolumn{2}{c}{ Aged rat } \\
& $\mathrm{V}_{\max }$ & $\mathrm{K}_{\mathrm{m}}$ & $\mathrm{V}_{\max }$ & $\mathrm{K}_{\mathrm{m}}$ \\
\hline Cortical regions & $17.5 \pm 2.4$ & $2.3 \pm 0.5$ & $10.5 \pm 3.3^{*}$ & $1.0 \pm 0.2^{*}$ \\
Subcortical structures & $16.1 \pm 1.1$ & $3.0 \pm 0.7$ & $6.3 \pm 1.1^{*}$ & $1.7 \pm 0.1^{*}$ \\
\hline
\end{tabular}

Each value is expressed as the mean \pm S.E. for five rats. Uptake of $\left[{ }^{3} \mathrm{H}\right]$-choline chloride was carried out at $37^{\circ} \mathrm{C}$ for $4 \mathrm{~min}$ at each concentration of radioligand. $V_{\max }$ and $K_{m}$ values were determined from Lineweaver-Burk double reciprocal plots of values obtained from graphic representations of the kinetic data. $\mathrm{V}_{\max }:$ pmol/min per $\mathrm{mg}$ protein, $\mathrm{K}_{\mathrm{m}}: \mu \mathrm{M},{ }^{*}: \mathrm{P}<0.05$, compared with young rats.

$\left[{ }^{3} \mathrm{H}\right]-\mathrm{QNB}$ increased in the cortex with age, but that the maximal capacity of muscarinic binding decreased in the cerebral cortex, striatum and hippocampus of 24-monthold Fischer 344 rats. These findings agree with our present results from male, 24-month-old Sprague-Dawley rats.
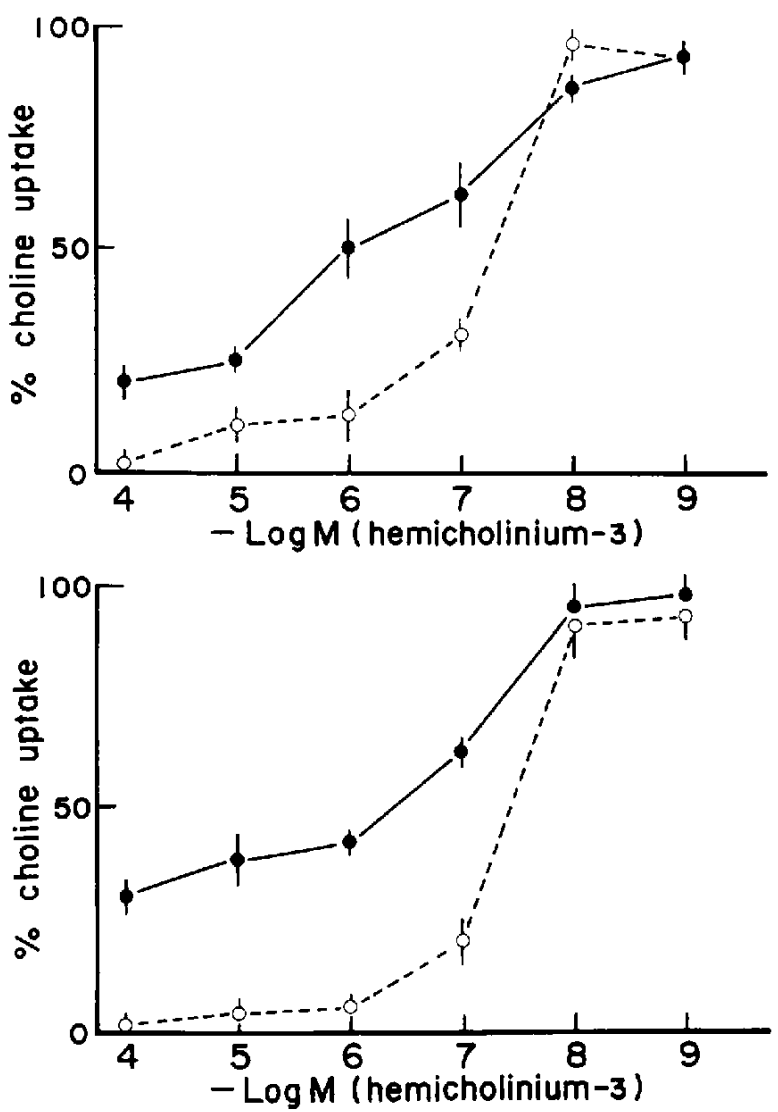

Fig. 4. Inhibition by hemicholinium-3 (HC-3) of sodium-dependent high affinity choline uptake in young and aged rat brain. After incubation with crude synaptosomes and various concentratons of $\mathrm{HC}-3$ in oxygenated $\left(95 \% \mathrm{O}_{2}-5 \% \mathrm{CO}_{2}\right)$ Krebs-Ringer bicarbonate buffer at $37^{\circ} \mathrm{C}$ for $5 \mathrm{~min},\left[{ }^{3} \mathrm{H}\right]$-choline chloride was added and incubated for another $4 \mathrm{~min}$. Symbols with bars represent the mean \pm S.E. of three separate experiments. Top: cerebral cortex, bottom: subcortical structure. Aged: - - -, young: - - $\bigcirc$ - rat brain.
Haba et al. (32) and Ogawa et al. (12) showed that the $\mathrm{mAChR}$ level was markedly reduced in all brain regions of aged Fischer rats, but found no change in $K_{d}$. Other reports show a decrease in muscarinic receptor binding sites in the cortex, but no change in the hippocampus of Sprague-Dawley (13), Fischer $344(33,34)$ or Wistar $(35)$ aged rats. These differences could be due in part to different strains or species $(13,14)$, tissue sampling $(16,17)$ or assay procedures (18). Michalek et al. (14) also reported significant strain-related differences in muscarinic receptor sites in three brain areas of Fischer 344 and Wistar male rats. They also explained the need to consider genotype in the assessment of age-related cholinergic deficits in animal models. In the present study, the value of $B_{\max }$ decreased significantly with age, especially in the SS, and the value of $K_{d}$ also decreased. This finding may show that the age-dependent decrease in $B_{\max }$ of muscarinic receptors results from the increase in muscarinic receptor affinity with age.

Muscarinic binding sites can be divided into two classes: $\mathbf{M}_{1}$ receptors, which have a high affinity for pirenzepine, and $\mathrm{M}_{2}$ receptors, which have a low affinity for this muscarinic antagonist $(36,37)$. The effects of aging on these subtypes of muscarinic receptors has been studied using various radioligands. Watson et al. (38) found an age-related decline in $\mathbf{M}_{1}$-receptor binding in the cortex, striatum, hippocampus and hypothalamus using $\left[{ }^{3} \mathrm{H}\right]-$ pirenzepine. Schwarz et al. (39) also found an age-related decrease in $\mathrm{M}_{1}$-receptors in the cortex of rats using the same selective $\mathbf{M}_{1}$-receptor antagonist. However, Sirviö et al. (40) reported that the maximal number of $M_{1}$ binding sites was unaltered in the cortex and hippocampus as rats aged. The present study found that pirenzepine, a muscarinic antagonist, bound with high affinity to $M_{1}$ receptors, inhibiting $\left[{ }^{3} \mathrm{H}\right]-\mathrm{QNB}$ binding in both aged and young rats. No age-related differences were found in the amount atropine-inhibited $\left[{ }^{3} \mathrm{H}\right]-\mathrm{QNB}$ binding in the $\mathrm{CR}$, but in the SS of aged rats, $\left[{ }^{3} \mathrm{H}\right]-\mathrm{QNB}$ binding was reduced by $20 \%$ in the presence of low concentrations of atropine. This indicates the existence of muscarinic receptors highly sensitive to atropine in aged rats. Although the relation- 
ship between this atropine-sensitive receptor and the $M_{1}$ receptor is unclear, it may involve some alteration at the muscarinic receptor sites of the postsynaptic membrane with aging.

Choline acetyltransferase (ChAT) is found in the brain in considerable excess and thus does not limit the rate of ACh synthesis, but it is generally agreed that the level of ChAT activity is a sensitive marker of changes in cholinergic innervation. Age-related decreases in ChAT are sometimes found in animal studies of normal aging. Some of these studies report a decrease with age in ChAT activity in the cerebral cortex and corpus striatum $(13,14,31,32$, $41)$, while others report no change $(39,40)$. Although these age-related differences in ChAT activity from animal studies may be due to differences in strain or species $(13,14)$, sex $(15)$, tissue sampling $(16,17)$ or assay procedures (18), these differences alone do not adequately explain the discrepancies.

An age-dependent decline of cholinergic activity is also supported by an analysis of biochemical markers in their terminal sites. Specifically, the current study has demonstrated that $\mathrm{AChE}$ activity is reduced with aging in all brain regions. These findings are in good agreement with previous reports $(11,14,42)$. In the present study, the $\mathrm{V}_{\max }$ values of ChAT and AChE activity decreased during aging, resulting in a decreased quantity of enzymes. The $\mathrm{V}_{\max }$ value of ChAT activity decreased more during aging in the SS than in the CR. The reduced synthesis of ACh found to occur in the rodent brain during aging may be due to the decrease in ChAT activity.

Additionally, decreased levels of AChE were found in both the CR and the SS in the aged rats. Because of the decrease in ChAT activity, which is considered to be a more reliable presynaptic marker of the cholinergic system, the low levels of AChE may be due to a loss of postsynaptic enzyme activity.

It is commonly believed that sodium-dependent high affinity choline uptake is by means of $\mathrm{Na}^{+}$transport $\left(\mathrm{Na}^{+}\right.$ channel) at the surface of the synaptic membrane of the presynaptic nerve terminals and is one of the rate-limiting steps in acetylcholine synthesis. Thus, given the observation that acetylcholine synthesis is diminished during aging, it is interesting to consider the possible role of agerelated changes in sodium-dependent high affinity choline uptake. An age-dependent reduction of sodium-dependent high affinity choline uptake was shown by Sherman et al. (43) and Sirviö et al. (44), but other studies did not confirm it $(45,46)$. In the current study, a significant, agerelated decrease in choline uptake was found in both the $\mathrm{CR}$ and the SS resulting from the decreased values of $\mathrm{K}_{\mathrm{m}}$ and $V_{\max }$. Thus, decreased sodium-dependent high affinity choline uptake may be due to a reduced number of carrier molecules for the presynaptic choline (44).
The availability of $\left[{ }^{3} \mathrm{H}\right]$-hemicholinium-3 $\left(\left[{ }^{3} \mathrm{H}\right]-\mathrm{HC}-3\right)$, a potent, reversible inhibitor of sodium-dependent high affinity choline uptake, has led to the development of the ligand-binding method to label sodium-dependent choline uptake sites $(47,48)$. In the current study, the in vitro effects of HC-3 were investigated in aged and young rat brain synaptosomes. In young rat brain, the uptake was markedly inhibited at low concentrations of $\mathrm{HC}-3$, but in aged brain, it was not inhibited completely, even at a $\mathrm{HC}$ 3 concentration of $10^{-4} \mathrm{M}$. These results indicate that the age-related decline in sodium-dependent high affinity choline uptake is due to conformational changes or the occupation of the binding sites by lipids and unknown endogenous ligands.

In 24-month-old Sprague-Dawley rats, the cholinergic markers of ChAT and AChE activity, numbers of $\mathrm{mAChR}$ and sodium-dependent high affinity choline uptake all decreased nearly $30-45 \%$ with age. However, the ability of choline uptake in presynaptic membranes and function of muscarinic receptors in postsynaptic membranes was maintained by the increase in the remaining binding site affinity with age. Moreover, it has been suggested that the heterogeneity of the muscarinic receptor and sodium-dependent high affinity choline uptake sites could be studied using sulfhydry reagents, metal ions, preferences for specific ligands and displacing agents (43, 49,50 ).

Table 5 summarizes the data from studies of mAChR, ChAT, AChE and sodium-dependent high affinity choline uptake (SDHACU) of aged rat brains compared to those of young rats. The data reviewed here suggested that $B_{\max }$ or $V_{\max }$ values of these markers were simultaneously decreased in both pre- and postsynaptic nerve terminals of aged rat brains. However, it is considerd that aged rats strive to maintain $\mathrm{MAChR}$ and SDHACU functions that were decreasing during natural aging by increasing these affinities, while the decreased AChE and ChAT activities were associated with only reductions of the enzyme molecule itself with advancing aging. Moreover, it appears that age-relatedly, these changes occurred to greater extents in some parts of the subcortical structures (including hippocampus, globus pallidus, thalamus, nucleus basalis of Meynert, caudate nucleus, putamen and striatum). These observations suggest that the functioning of the cholinergic system in subcortical structures is impaired predominantly during natural aging. However, it is known that some regional differences in these age-related changes are present.

To investigate these changes in the dynamic properties of cholinergic input to the hippocampus and cortex, further studies are need to clarify the regional variations within the basal forebrain. 
Table 5. Comparison of cholinergic markers in aged rats and young rats

\begin{tabular}{lccc}
\hline & $\mathrm{K}_{\mathrm{m}}$ or $\mathrm{K}_{\mathrm{d}}$ & $\mathrm{V}_{\max }$ or $\mathrm{B}_{\max }$ & Affinity against inhibitor \\
\hline Cotrical regions & & & \\
mAChR & $14 \% \downarrow$ & $30 \% \downarrow$ & no change \\
AChE & \pm & $28 \% \downarrow$ & no change \\
ChAT & \pm & $28 \% \downarrow$ & no change \\
SDHACU & $57 \% \downarrow$ & $40 \% \downarrow$ & low sensitive to HC-3 \\
Subcortical structures & & $50 \% \downarrow$ & high sensitive to atropine \\
mAChR & $50 \% \downarrow$ & $35 \% \downarrow$ & no change \\
AChE & \pm & $30 \% \downarrow$ & low sensitive to PCMB \\
ChAT & \pm & $60 \% \downarrow$ & low sensitive to HC-3 \\
SDHACU & $43 \% \downarrow$ &
\end{tabular}

mAChR: muscarinic receptor, AChE: acetylcholinesterase, ChAT: choline acetyltransferase, SDHACU: sodium-dependent high affinity choline uptake. \pm or no change: did not observe the differences between aged rats and young rats.

\section{REFERENCES}

1 Pradham SN: Minireview: Central neurotransmitters and aging. Life Sci 26, 1643-1656 (1980)

2 McGeer EG and McGeer PL: Neurotransmitters in normal aging. In Geriatrics I, Edited by Pllatt D, pp 263-282, SpringerVerlag, Berlin (1982)

3 Hepler DJ, Olton DS, Wenk GL and Coyle JT: Lesions in nucleus basalis magnocellularis and medial septal area of rats produce qualitatively similar memory impairments. J Neurosci 5, 866-873 (1985)

4 Smith G: Animal models of Alzheimer's disease: experimental cholinergic denervation. Brain Res Rev 13, 103-118 (1988)

5 Davies $P$ and Maloney AJF: Selective loss of central cholinergic neurons in Alzheimer's disease. Lancet 2, 1403 (1976)

6 Perry EK, Perry RH, Gibson PH, Blessed G and Tomlinson BE: A cholinergic connection between normal aging and senile dementia in the human hippocampus. Neurosci Lett 6, 85-89 (1977)

7 Perry EK, Blessed G, Tomlinson BE, Perry RH, Crow TJ, Cross AJ, Dockray GJ, Dimaline R and Arregui A: Neurochemical activities in human temporal lobe related to aging and Alzheimer-type changes. Neurobiol Aging 2, 251-256 (1981)

8 White P, Goodhardt MJ, Keet JP, Hiley CR, Carrasco LH, Williams IEI and Bowen DM: Neocortical cholinergic neurons in elderly people. Lancet 1, 668-670 (1977)

9 Whitehouse PJ, Price DL, Struble RG, Clark AW, Coyle JT and Delong MR: Alzheimer's disease and senile dementia: loss of neurons in the basal forebrain. Science 215, 1237-1239 (1982)

10 Meek JL, Bertilsson L, Cheney DL, Zsilla G and Costa E: Aging induced changes in acetylcholine and serotonin content of discrete brain nuclei. J Gerontol 32, 129-131 (1977)

11 Sirviö J, Valjakka A, Jolkkonen J, Hervonen A and Riekkinen PJ: Cholinergic enzyme activities and muscarinic binding in the cerebral cortex of rats of different age and sex. Comp Biochem Physiol 90C, 245-248 (1988)

12 Ogawa N, Nomura M, Haba K, Asanuma M, Tanaka K, Hori $\mathrm{K}$ and Mori A: Effects of dihydroergotoxine on central choliner- gic neuronal systems and discrimination learning test in aged rats. Brain Res 586, 229-234 (1992)

13 Strong R, Hicks P, Hsu L, Bartus RT and Enna SJ: Age-related alterations in the rodent brain cholinergic system and behavior. Neurobiol Aging 1, 59-63 (1980)

14 Michalek H, Fortuna S and Pintor A: Age-related differences in brain choline acetyltransferase, cholinesterases and muscarinic receptor sites in two strains of rats. Neurobiol Aging 10, 143- 148 (1989)

15 Luine VN, Renner KJ, Heady S and Jones KJ: Age and sex-dependent decreases in ChAT in basal forebrain nuclei. Neurobiol Aging 7, $193-198$ (1986)

16 Dravid AR: Deficits in cholinergic enzymes and muscarinic receptors in the hippocampus and striatum of senescent rats: effect of chronic hydergine treatment. Arch Int Pharmacodyn Ther 264, 195-202 (1983)

17 Springer JE, Tayrien MW and Loy R: Regional analysis of agerelated changes in the cholinergic system of the hippocampal formation and basal forebrain of the rat. Brain Res 407 , 180- 184 (1987)

18 Waller SB, Ingram DK, Reynolds MA and London ED: Age and strain comparisons of neurotransmitter synthetic enzyme activities in the mouse. J Neurochem 41, 1421-1428 (1983)

19 Mohan C and Radha E: Age-dependent kinetic changes in the activities of central cholinergic enzymes. Exp Gerontol 13, 349-356 (1978)

20 Sastry BVR, Janson VE, Jaiswal $N$ and Tayeb OS: Changes in enzymes of the cholinergic system and acetylcholine release in the cerebra of aging male Fischer rats. Pharmacology 26, 61-72 (1983)

21 Johnston MV, McKinney M and Coyle JT: Neocortical cholinergic innervation: A description of extrinsic and intrinsic components in the rat. Exp Brain Res 43, 159-172 (1981)

22 Flicker C, Dean RL, Watkins DL, Fisher SK and Bartus RT: Behavioral and neurochemical effects following neurotoxic lesions of a major cholinergic input to the cerebral cortex in the rat. Pharmacol Biochem Behav 18, 973-981 (1983)

23 Walsh TJ, Tilson HA, DeHaven DL, Mailman RB, Fisher A and Hanin I: AF64A, a cholinergic neurotoxin, selectively 
depletes acetylcholine in hippocampus and cortex, and produces long-term passive avoidance and radial-arm maze deficits in the rat. Brain Res 321, 91-102 (1984)

24 Ueki A and Miyoshi K: Effects of cholinergic drugs on learning impairment in ventral globus pallidus-lesioned rats. J Neurol Sci 90, 1-21 (1989)

25 Yamamura HI and Snyder SH: Muscarinic cholinergic binding in rat brain. Proc Natl Acad Sci USA 71, 1725-1729 (1974)

26 Fonnum F: A rapid radiochemical method for determination of choline acetyltransferase. J Neurochem 24, 407-409 (1975)

27 Ellman GL: A new and rapid colorimetric determination of acetylcholinesterase activity. Biochem Pharmacol 7, 88-95 (1961)

28 Sorimachi $\mathbf{M}$ and Kataoka $\mathrm{K}$ : Choline uptake by nerve terminals: a sensitive and a specific marker of cholinergic innervation. Brain Res 72, 350-353 (1974)

29 Lowry OH, Rosebrough NJ, Farr AL and Randall RJ: Protein measurement with Folin phenol reagent. J Biol Chem 193, 265-275 (1951)

30 Prince AK: Choline acetyltransferase. Methods Enzymol, 17B, $788-797$ (1971)

31 Waller SB and London ED: Choline acetyltransferase activity and muscarinic binding in brain regions of aging Fischer-344 rats. Neurochem Int 14, 483-490 (1989)

32 Haba K, Ogawa N, Kawata $M$ and Mori A: A method for parallel determination of choline acetyltransferase and muscarinic cholinergic receptors: application in aged-rat brain. Neurochem Res 13, 951-955 (1988)

33 Pedigo NW Jr and Polk DM: Reduced muscarinic receptor plasticity in frontal cortex of aged rats after chronic administration of cholinergic drugs. Life Sci 37, $1443-1449$ (1985)

34 Pedigo NW Jr, Minor LD and Krumrei TN: Cholinergic drug effects and brain muscarinic receptor binding in aged rats. Neurobiol Aging 5, 227-233 (1984)

35 Noda Y, McGeer PL and McGeer EG: Lipid peroxides in brain during aging and Vitamin $\mathrm{E}$ deficiency: possible relations to changes in neurotransmitter indices. Neurobiol Aging 3, $173-178$ (1982)

36 Hammer R, Berrie CP, Birdsall NJM, Burgen ASV and Hulme EC: Pirenzepine distinguishes between different subclasses of muscarinic receptors. Nature 283, 90-92 (1980)

37 Watson M, Yamamura HI and Roeske WR: A unique regula- tory profile and regional distribution of $\left[{ }^{3} \mathrm{H}\right]$ pirenzepine binding in the rat provide evidence for distinct $\mathbf{M}_{1}$ and $\mathbf{M}_{2}$ muscarinic receptor subtypes. Life Sci 32, 3001-3011 (1983)

38 Watson M, Roeske WR and Yamamura HI: Decreased muscarinic receptor density in the aged rat brain. Proc West Pharmacol Soc 31, 61-65 (1988)

39 Schwarz RD, Bernabei AA, Spencer CJ and Pugsley TA: Loss of muscarinic M1 receptors with aging in the cerebral cortex of Fischer 344 rats. Pharmacol Biochem Behav 35, 589-593 (1990)

40 Sirviö J, Hervonen A and Riekkinen PJ: Cholinergic binding in the hippocampus of the aging male rat. Comp Biochem Physiol 90C, $161-163$ (1988)

41 McGeer EG, Fibiger HC, McGeer PL and Wickson V: Aging and brain enzymes. Exp Gerontol 6, 391 - 396 (1971)

42 Altavista MC, Rossi P, Bentivoglio AR, Crociani $\mathrm{P}$ and Albanese A: Aging is associated with a diffuse impairment of forebrain cholinergic neurons. Brain Res 508, 51 - 59 (1990)

43 Sherman KA, Kuster JE, Dean RL, Bartus RT and Friedman E: Presynaptic cholinergic mechanisms in brain of aged rats with memory impairment. Neurobiol Aging 2, 99-104 (1981)

44 Sirviö $\mathbf{J}$, Hervonen $\mathbf{A}$ and Riekkinen PJ: Sodium dependent uptake of ${ }^{3} \mathrm{H}$-choline in the cerebral cortex of aging male rats. Pharmacol Toxicol 62, 227-229 (1988)

45 Gallagher M, Burwell RD, Kodsi MH, McKinney M, Southerland S, Vella-Rountree L and Lewis MH: Markers for biogenic amines in the aged rat brain: relationship to decline in spatial learning ability. Neurobiol Aging 11, 507-514 (1990)

46 Decker MW: The effects of aging on hippocampal and cortical projections of the forebrain cholinergic system. Brain Res Rev 12, 425-438 (1987)

47 Sandberg K and Coyle JT: Characterization of $\left[{ }^{3} \mathrm{H}\right]$ hemicholinium-3 binding associated with neuronal choline uptake sites in rat brain membranes. Brain Res 348, $321-330$ (1985)

48 Forloni $\mathrm{G}$ and Angeretti N: Decreased ${ }^{3} \mathrm{H}$-hemicholinium binding to high affinity choline uptake sites in aged rat brain. Brain Res 570, 354-357 (1992)

49 Hoss W and Ellis J: Muscarinic receptor subtypes in the central nervous system. Int Rev Neurobiol 26, 151-199 (1985)

50 Peralta EG, Ashkenazi A, Winslow JW, Smith DH, Ramachandran $\mathrm{J}$ and Capon DJ: Distinct primary structures, ligand-binding properties and tissue-specific expression of four human muscarinic acetylcholine receptors. EMBO J 6, 3923-3929 (1987) 